\title{
Propolis and Potential Use in Food Products
}

\author{
Ezgi Demir Özer ${ }^{1, a, *}$ \\ ${ }^{1}$ Department of Gastronomy and Culinary Arts, School of Applied Sciences, Cappadocia University, 50420 Nevşehir, Turkey \\ *Corresponding author

A R T I C L E I N F O A B S T R A C T \\ Review Article \\ Propolis is attracting great interest due to functional effects such as antibacterial, antioxidant and \\ anticancer. Therefore, studies about the use of propolis in food products and increasing propolis \\ consumption in human nutrition have increased in recent years. Propolis contains phenolic \\ compounds, essential oils, aromatic acids and waxes which are responsible for biological effects. \\ Received : 17/01/2020 \\ Many factors such as plant resources, geographical regions and environmental conditions affect the \\ chemical composition of propolis. Propolis enrichment in food products to improve the nutritional \\ value, quality and functionality of food have been investigated in many studies. Furthermore, it was \\ reported that propolis can meet the demand of consumers about the use of natural food additive in \\ food manufacturing. The aim of the present study was to introduce the physicochemical composition \\ and biological activity of propolis and review the studies about its applications in food products. \\ Keywords:
}

Propolis

Food

Protection

Preservative

Antimicrobial

ezgi.ozer@kapadokya.edu.tr (i) https://orcid.org/0000-0002-3525-5172|

(c) (1) () This work is licensed under Creative Commons Attribution 4.0 International License

\section{Introduction}

Propolis is a bee product that is a mixture of beeswax and resins prepared by the honeybee (Apis mellifera) (Casquete et al., 2016). The propolis name comes from two ancient Greek wordings which are pro (in front of, at the entrance to) and polis (city, community) (VS Bankova et al., 2000). The bees produce propolis for the use of as a protective barrier, damage repairer and thermal insulator (Cardoso et al., 2011). Additionally, propolis is used by bees to protect against pathogenic microorganisms (Falcao et al., 2010). Its chemical composition varies depending on plant origins and geographical locations. Therefore, it has been reported in the literature that hundreds of different compounds were detected in propolis (Bankova, de Castro, \& Marcucci, 2000).

Propolis has gained attention in recent years because of its possible biological properties such as antiviral, antibacterial, cariostatic, antioxidant, hepatoprotective and anticancer (Burdock, 1998, Moreira et al., 2008, Valente et al., 2011, Silva et al., 2012, Cottica et al., 2015). Therefore, there has been an increased demand in ways to benefit from these potential impacts by enriching the nutritional value, quality and functionality of food products (Moreira et al.,
2008). Propolis has been investigated to use in some food products as an antioxidant, antimicrobial and flavoring agent in many studies (Yang et al., 2010, Bernardi et al., 2013, Vargas-Sanchez et al., 2014, Cottica et al., 2015, Casquete et al., 2016).

\section{Physicochemical Composition of Propolis}

The source of propolis composition originates from plants, bee metabolites and propolis construction materials. However, the composition of propolis mainly depends on plant materials, plant species, season, climate, genetic diversity in the queen bee (Toreti et al., 2013). Therefore, the chemical composition of propolis is highly variable and affects the variability of plant species growing around the hive and geographic location (Russo et al., 2002, de Groot, 2013).

Generally, propolis is composed of resins $(50 \%)$, wax and fatty acids (30\%), essential and aromatic oils (10\%), polyphenols and flavonoids $(10 \%)$, pollen $(5 \%)$, vitamins and minerals $(5 \%)$ approximately (Table 1) (Noori et al., 2012). Furthermore, propolis is the major source of phenolic acids and its esters, flavonoid aglycones, amino acids, 
ketones, phenolic aldehydes, alcohols, sesquiterpenes, steroids, coumarins, and the inorganic compound. (Burdock, 1998, Sforcin, 2007, Değirmencioğlu, 2018).

Huang et al., (2014) have stated that chemical profiles of common propolis type which is called the poplar type propolis from different countries such as Korea, China, Taiwan, New Zealand and European countries are similar. While poplar type propolis has high-level flavonoids and phenylpropanoids, it is called green and red propolis which is obtained from the tropical zone and rich in coumaric acid and some isoflavonoids.

The studies in the literature have shown that the propolis samples collected from Europe are rich in phenolic compounds, flavonoids, aromatic oil and samples collected from Australia and South America is rich in diand triterpenes as well as phenolic compounds (Sforcin, 2007, Seidel et al., 2008).

\section{The Biological Activity of Propolis}

Several studies have shown that propolis has different biological effects such as antimicrobial (Oliveira et al., 2010, Silva et al., 2012, Bueno-Silva et al., 2017), anticarcinogenic (Kouidhi et al., 2010), anti-inflammatory (Borrelli et al., 2002, De Barros et al., 2008), antioxidant (Kumazawa et al., 2004, Russo et al., 2004, Daleprane \& Abdalla, 2013, Zam and Othman, 2018), anticancer (Watanabe et al., 2011, Turan et al., 2015). Havsteen, (1983) has stated that a significant portion of these biological effects is due to flavonoids in propolis. Therefore, the amount of flavonoids in propolis is very important to benefit from the biological activity of propolis.

Propolis is rich in biologically active compounds that have strong antioxidant properties (Değirmencioğlu, 2018). Many compounds such as kaempferol, phenethyl caffeate especially flavonoids and phenolic compounds, are thought to be responsible for the formation of antioxidant effects of propolis (Burdock, 1998, Bankova, 2005). Burdock, (1998) has stated that the antioxidant activity of propolis may be related to flavonoids. Flavonoids in propolis are potential antioxidant compounds that have scavenging ability of free radicals, binding of heavy metal ions and biological polymers. In addition, caffeic acid phenethyl ester in propolis inhibits reactive oxygen species production (Hosnuter et al., 2004). Also, caffeic acid phenethyl ester has superoxide radical scavenger effect and lipid peroxidation inhibitory effect (Russo et al., 2002).
The studies have shown that propolis extracts have antibacterial, antifungal and antiviral activity (Burdock, 1998, Valente et al., 2011, Silva et al., 2012). Silva et al., (2012) and Vardar-Unlu et al., (2008) have reported that propolis has greater activity against Gram-positive bacteria than Gram-negative bacteria. This may be related to the differences in the cell wall of gram-negative and positive bacteria. Takaisikikuni and Schilcher, (1994) have indicated that propolis exhibits antibacterial effects by protein synthesis, cell division and bacterial growth inhibition. Additionally, antibacterial properties of propolis increase in a dose-dependent (Ugur \& Arslan, 2004). The antiviral effect of propolis is variable depending on virus types. Propolis inhibits the required enzyme for the multiplication of the DNA virus. Thus, it showed high antiviral activity in DNA/RNA viruses such as influenza and herpes polio (Silva-Carvalho et al., 2015, Yildirim et al., 2016). Flavonoids in the propolis are mainly responsible for the antiviral effect (Silva et al., 2012). Antifungal activity is affected by the chemical composition of propolis (Silva-Carvalho et al., 2015). Quiroga et al., (2006) have indicated that flavonoids such as galangin and pinocembrin are mainly responsible for the antifungal effect.

Propolis, especially caffeic acid phenethyl ester in it, shows the anti-inflammatory effect by preventing the pathways to inflammation. Propolis inhibits the synthesis of leukotriene and prostaglandin and suppresses the expression of transcription factors of the nuclear factor. These are playing an important role in inflammation so that propolis reduces the levels of inflammatory cytokines and interleukins in these ways (Fan et al., 2015, FunakoshiTago et al., 2015). On the other hand, in some studies, it has been reported that propolis can prevent specific oncogene signaling pathways and modulate the tumor microenvironment. And this way, it can also decrease the cancer stem cell population as it provides to decrease in cell proliferation (Sawicka et al., 2012, Bhargava et al., 2018, Ishida et al., 2018).

As a result, there are several positive effects on human health such as improvement of ventilatory functions, antibacterial and antifungal activities, gut and throat health, immune system and blood circulation (Duarte et al., 2003, Bankova, 2005, Sforcin, 2007). However, no health claim has been recognized for propolis by the European Food Safety Authority (EFSA) (EFSA, 2010).

Table 1. The chemical composition of poplar type propolis (Burdock, 1998, Barlak, 2009, Değirmencioğlu, 2018)

\begin{tabular}{|c|c|c|}
\hline & Compounds & Amount (\%) \\
\hline Resins & $\begin{array}{l}\text { Flavonoids (rhamnocitrin, acacethin, quercetin, macarangin) } \\
\text { Terpens (oleonane, lupane, ursane and lanostane) } \\
\text { Coumarins } \\
\text { Phenolic compounds (Caffeic acid, ferulic acid etc.) }\end{array}$ & $42-58$ \\
\hline Wax and oils & $\begin{array}{l}\text { Plant waxs } \\
\text { Oleic and palmitic acids } \\
\text { Essential and aromatic oils }\end{array}$ & $33-47$ \\
\hline Pollen & $\begin{array}{l}\text { Proteins } \\
\text { Free aminoacids (glutamate, proline, aspartate, leucine and lysine) } \\
\text { Vitamins (A, B, C, E) } \\
\text { Elements ( } \mathrm{Mn}, \mathrm{Cu}, \mathrm{Al}, \mathrm{Fe}, \mathrm{Co}, \mathrm{Zn}, \mathrm{Ag}, \mathrm{Ca}, \mathrm{Mg})\end{array}$ & $3-5$ \\
\hline $\begin{array}{l}\text { Other } \\
\text { components }\end{array}$ & $\begin{array}{l}\text { Ketones } \\
\text { Laktons } \\
\text { Steroids } \\
\text { Sugar }\end{array}$ & $2-5$ \\
\hline
\end{tabular}


Table 2. Applications of propolis in food products

\begin{tabular}{|c|c|c|c|}
\hline Food Products & Properties of Propolis & Results and Comments & References \\
\hline Fish burgers & $\begin{array}{l}\text { Microencapsulated propolis } \\
\text { extract }\end{array}$ & $\begin{array}{l}\text { Improving phenolic content and } \\
\text { antioxidant activity }\end{array}$ & Spinelli et al. (2015) \\
\hline Fish fillet & Propolis extract in water & Improving microbial quality & $\begin{array}{l}\text { Duman and Ozpolat, } \\
(2015)\end{array}$ \\
\hline Beef patties & Propolis extract in ethanol & $\begin{array}{l}\text { Improving lipid oxidation stability } \\
\text { during storage } \\
\text { Inhibition of mesophilic and } \\
\text { psychotropic bacteria }\end{array}$ & $\begin{array}{l}\text { Vargas-Sanchez et al. } \\
\text { (2014) }\end{array}$ \\
\hline $\begin{array}{l}\text { Fermented } \\
\text { sausage }\end{array}$ & Propolis extract in ethanol & $\begin{array}{l}\text { Inhibition of Micrococcaceae, yeast } \\
\text { and molds on the surface of fermented } \\
\text { sausage }\end{array}$ & Ozturk (2015) \\
\hline Sausage & Propolis extract in ethanol & $\begin{array}{l}\text { Improving lipid oxidation stability } \\
\text { Improving sensorial quality }\end{array}$ & Ali et al. (2010) \\
\hline Sausage & Propolis extract in ethanol & Improving shelf life & Han and Park (2002) \\
\hline Salami & $\begin{array}{l}\text { Propolis extract in ethanol and } \\
\text { microencapsulated propolis } \\
\text { extract }\end{array}$ & $\begin{array}{l}\text { Improving shelf life } \\
\text { Improving lipid oxidation stability }\end{array}$ & $\begin{array}{l}\text { Bernardi et al., } \\
\quad(2013)\end{array}$ \\
\hline Sausage & Propolis extract in ethanol & $\begin{array}{l}\text { Antimicrobial activity against some } \\
\text { pathogenic microorganisms }\end{array}$ & $\begin{array}{c}\text { Gutiérrez-Cortés and } \\
\text { Suarez Mahecha } \\
(2014)\end{array}$ \\
\hline Milk & Propolis extract in ethanol & Inhibition of Listeria monocytogenes & $\begin{array}{l}\text { Thamnopoulos et al. } \\
\text { (2018) }\end{array}$ \\
\hline Dairy beverage & $\begin{array}{l}\text { Propolis extract in ethanol and } \\
\text { water }\end{array}$ & Improving antioxidant activity & Cottica et al. (2015) \\
\hline Ice-cream & Propolis extract in ethanol & Inhibition of S. aureus & $\begin{array}{l}\text { El-Bassiony et al. } \\
\text { (2012) }\end{array}$ \\
\hline Yogurt & Propolis & Improving shelf life & Çifci (2015) \\
\hline Orange juice & Propolis & Antifungal effect & Yang et al. (2017) \\
\hline $\begin{array}{l}\text { Apple, grape, } \\
\text { orange juice }\end{array}$ & Propolis & Antifungal effect & Koc et al. (2007) \\
\hline $\begin{array}{l}\text { Fruits (banana, } \\
\text { grapefruit, } \\
\text { grape) }\end{array}$ & Propolis extract in ethanol & $\begin{array}{l}\text { Improving textural quality } \\
\text { Prevent weight losses }\end{array}$ & $\begin{array}{l}\text { Passos et al. (2016) } \\
\text { Ozdemir et al. (2010) } \\
\text { Pastor et al. (2011) }\end{array}$ \\
\hline Quail eggs & Propolis extract in methanol & Improving shelf life & Akpinar et al. (2015) \\
\hline Olive oil & Propolis extract in methanol & $\begin{array}{l}\text { Improving antioxidant activity and } \\
\text { shelf life }\end{array}$ & Ozcan (2000) \\
\hline $\begin{array}{l}\text { A la piedra' } \\
\text { turro'n which is } \\
\text { a type of } \\
\text { confection }\end{array}$ & Propolis & $\begin{array}{l}0.05 \% \text { propolis were determined as } \\
\text { suitable for the instrumental aroma } \\
\text { profile and the descriptive sensory } \\
\text { profile of this confection. Also the } \\
\text { level may be improve its health } \\
\text { benefits by incorporating into the } \\
\text { consumers }\end{array}$ & (Narbona et al. 2010) \\
\hline
\end{tabular}

\section{Use of Propolis in Foods}

The consumption of propolis should be increased in the human diet in order to provide the positive effects of its biological activities in human health. Also using propolis meets the consumer demand for the use of natural antioxidants and antimicrobials instead of synthetic food additives. Therefore, the enrichment of food products with propolis as a natural food additive and improving food quality has become an interesting subject in recent years (Pobiega et al., 2018). Many of the compounds in propolis have been used as food additives and these are generally recognized as safe (GRAS) substances (Burdock, 1998, Silva-Carvalho et al., 2015). Although it can be said that propolis is safe to consume, adverse effects such as dermatitis may be observed in some people (de Groot,
2013). It is indicated that humans can consume $1.4 \mathrm{mg} / \mathrm{kg}$ body weight/day or approximately $70 \mathrm{mg} /$ day as a safe dose (Burdock, 1998). Also, the study aimed at an acceptable amount of propolis in a designed food product with honey and propolis determined the suitable level as a maximum of $0.5 \%$ propolis content (Osés et al., 2015).

Studies have reported that propolis generally is used in various food formulations such as meat, dairy, juice, fruits, oils and seafood to improve shelf-life, prevent lipid oxidation and provide health benefits for consumers (Table 2) (Ozcan, 2000, Ali et al., 2010, Vargas-Sanchez et al., 2014, Cottica et al., 2015, Spinelli et al., 2015, V Bankova et al., 2016). 
Propolis can be added to food formulation as an ingredient or applied to the food surface (Pobiega et al., 2018). However, the phenolic acid and other volatile compounds of propolis have a strong and incompatible taste and odor which is enough change the sensory properties of food, and so, the use of propolis in food products is still limited (da Silva et al., 2013, Spinelli et al., 2015). Narbona et al. (2010) added different propolis levels $(0.040 \%, 0.050 \%, 0.060 \%, 0.080 \%, 0.100 \%, 0.150 \%$ and $0.200 \%$ ) to "a la piedra' turro'n " which is a type of confection. The suitable level of propolis was determined as $50 \mathrm{mg}$ per $100 \mathrm{~g}$ a la piedra' turro' $\mathrm{n}$ for the instrumental aroma profile and the descriptive sensory profile.

Vargas-Sanchez et al., (2014) indicated that propolis extracts can be used to improve lipid oxidation stability and inhibit the microbial growth on beef patties during cold storage. Non-commercial propolis treatments $(2 \% \mathrm{w} / \mathrm{w})$ have shown the highest total phenolic content, free-radical scavenging activity and lipid oxidation stability. Furthermore, the growths of mesophilic and psychrotrophic bacteria in patties were inhibited by noncommercial propolis extract during storage. Similarly, it is indicated that Micrococcaceae, yeasts and molds on the surface of fermented sausage can be reduced by the use of propolis without adverse effects on its color and aroma properties (Ozturk, 2015). Han and Park, (2002) indicated that the shelf life of meat products by the use of propolis may be longer than potassium sorbate, which is currently used in meat products.

Gutiérrez-Cortés and Suarez Mahecha (2014) evaluated the in-vitro antimicrobial activity of the ethanol propolis extract on some pathogenic bacteria and their influence on the physicochemical and sensorial properties of sausages. The amount of ethanol propolis extract was determined at $0.8 \%$ which had antimicrobial activity against some pathogenic microorganisms and no negative effects on the physicochemical and sensorial characteristics of the product. They also have stated that propolis can be used in meat products as an alternative for nitrites. Spinelli et al., (2015) microencapsulated the ethanolic extracts of propolis to minimize the sensorial problems of propolis and used it to enhance the antioxidant properties of fish burgers. It was reported that the microencapsulation process has been successful to eliminate the strong odor of propolis, and phenolic content and antioxidant activity of fish burgers improved. Similarly, Bernardi et al., (2013) reported that Italian salami can be manufactured using encapsulated propolis as a replacement for sodium erythorbate.

There are many studies about the use of propolis in dairy products in the literature. Cottica et al., (2015) reported that the addition of ethanol and water extracts of propolis in dairy beverages showed the highest antioxidant capacity and the lowest aldehyde production during storage in light. Furthermore, some studies have shown that yogurt can be manufactured with propolis without any significant adverse effects except for some minor negative sensory effects (Çifci, 2015, Bilici, 2017). However, it stated that propolis at certain doses significantly inhibited Streptococcus salivarius subs. thermophilus bacteria and therefore, yogurt production may be negatively affected (Çifci, 2015). Similarly, the count of methicillin-resistant Staphylococcus aureus was reduced by using ethanol extract of propolis in ice cream (El-Bassiony et al., 2012). It is indicated that the propolis ethanolic extract into glycerol showed inhibition effects on Listeria monocytogenes at the end of storage time (30 days) (Thamnopoulos et al., 2018).

Post-harvest storage for fruits and vegetables is the most important stage which results in economic and nutritional losses. The causes of these losses are fungal and bacterial growth which can be prevented by propolis applications. Feas et al., (2014), Alvarez et al., (2015) and Alvarez et al., (2017) reported that ready-to-eat vegetables such as lettuces, leek and celery can be sanitized by propolis extracts. Also, propolis has an inhibition effect against some Penicillium species in fruits. Additionally, the use of propolis in some juices such as apple, grape, orange, and mandarin has shown that propolis is effective on mold and yeast as effective as sodium benzoate and potassium sorbate (Koc et al., 2007, Yang et al., 2017).

The antioxidant properties of propolis have also been tried to improve the storage stability of oils. Ozcan, (2000) reported that propolis had better antioxidant activity in olive oil as compared to butylated hydroxyanisole and butylated hydroxytoluene. Furthermore, the coating of quail eggs with propolis was effective for protecting the internal egg quality parameters and may help to slow the decrease in quality during storage (Akpinar et al., 2015).

\section{Conclusion}

Propolis is a natural preservative that has antifungal, antioxidant, antibacterial properties. Therefore, propolis can be used for food preservation as a natural preservative. However, strong odor and flavor, allergenic effect and variations in the composition of propolis limit its use in foods. Chemical composition and the dose of propolis are very important criteria for food preservation. So, more studies are needed on the use of propolis in the preservation and nutritionally enrichment of food into consideration the amounts that people can take daily.

\section{Acknowledgements}

The author wishes to thank the Scientific Projects Coordination Unit of Cappadocia University (Nevsehir, Turkey) for support (Project KÜN.2018-BAGP-002).

\section{References}

Akpinar GC, Canogullari S, Baylan M, Alasahan S, Aygun A. 2015. The use of propolis extract for the storage of quail eggs. J Appl Poultry Res, 24(4): 427-435.

Ali FH, Kassem GM, Atta-Alla OA. 2010. Propolis as a natural decontaminant and antioxidant in fresh oriental sausage. Vet Ital, 46(2): 167-172.

Alvarez MV, Ponce AG, Goyeneche R, Moreira MR. 2017. Physical Treatments and Propolis Extract to Enhance Quality Attributes of Fresh-Cut Mixed Vegetables. J Food Process Pres, 41(5).

Alvarez MV, Ponce AG, Moreira MR. 2015. Combined Effect of Bioactive Compounds and Storage Temperature on Sensory Quality and Safety of Minimally Processed Celery, Leek and Butternut Squash. J Food Safety, 35(4): 560-574.

Bankova V. 2005. Recent trends and important developments in propolis research. Evid-Based Compl Alt, 2(1): 29-32.

Bankova V, Popova M, Trusheva B. 2016. New Emerging Fields of Application of Propolis. Maced J Chem Chem En, 35(1): 1-11. 
Bankova VS, de Castro SL, Marcucci MC. 2000. Propolis: recent advances in chemistry and plant origin. Apidologie, 31(1): 315.

Barlak Y. 2009. Türk Propolisiekstraktlarının Prostat Kanser Hücre Serilerinin Proteomiğine Etkisi. (PhD), Karadeniz Technical University, Trabzon.

Bernardi S, Favaro-Trindade CS, Trindade MA, Balieiro JCC, Cavenaghi AD, Contreras-Castilo CJ. 2013. Italian-Type Salami with Propolis as Antioxidant. Ital J Food Sci, 25(4): 433-440.

Bhargava P, Grover A, Nigam N, Kaul A, Doi M, Ishida Y, Kakuta H, Kaul SC, Terao K, Wadhwa R. 2018. Anticancer activity of the supercritical extract of Brazilian green propolis and its active component, artepillin C: Bioinformatics and experimental analyses of its mechanisms of action. Int $\mathrm{J}$ Oncol, 52(3): 925-932.

Bilici C. 2017. Lepidium Meyenii Tozu ve Propolis Ekstarktı İlave Edilerek Fonksiyonel Özellikleri Geliştirilmiş Yoğurt Üretilmesi. (Master), Marmara University, İstanbul.

Borrelli F, Maffia P, Pinto L, Ianaro A, Russo A, Capasso F, Ialenti A. 2002. Phytochemical compounds involved in the anti-inflammatory effect of propolis extract. Fitoterapia, 73: S53-S63.

Bueno-Silva B, Marsola A, Ikegaki M, Alencar SM, Rosalen PL. 2017. The effect of seasons on Brazilian red propolis and its botanical source: chemical composition and antibacterial activity. Nat Prod Res, 31(11): 1318-1324.

Burdock GA. 1998. Review of the biological properties and toxicity of bee propolis (propolis). Food and Chemical Toxicology, 36(4): 347-363.

Cardoso SM, Ribeiro M, Ferreira IL, Rego AC. 2011. Northeast Portuguese propolis protects against staurosporine and hydrogen peroxide-induced neurotoxicity in primary cortical neurons. Food and chemical toxicology, 49(11): 2862-2868.

Casquete R, Castro SM, Jácome S, Teixeira P. 2016. Antimicrobial activity of ethanolic extract of propolis in "Alheira", a fermented meat sausage. Cogent Food \& Agriculture, 2(1): 1125773.

Cottica SM, Sabik H, Belanger D, Giroux HJ, Visentainer JV, Britten M. 2015. Use of propolis extracts as antioxidant in dairy beverages enriched with conjugated linoleic acid. Eur Food Res Technol, 241(4): 543-551.

Çifci F. 2015. Propolisin yoğurt üretiminde kullanılması. Yüksek Lisans Tezi (Master), Ondokuz Mayıs Universitesi, Samsun, 86 sayfa.

da Silva FC, da Fonseca CR, de Alencar SM, Thomazini M, Balieiro JCD, Pittia P, Fauaro-Trindade CS. 2013. Assessment of production efficiency, physicochemical properties and storage stability of spray-dried propolis, a natural food additive, using gum Arabic and OSA starchbased carrier systems. Food Bioprod Process, 91(C1): 28-36.

Daleprane JB, Abdalla DS. 2013. Emerging roles of propolis: antioxidant, cardioprotective, and antiangiogenic actions. Evid-Based Compl Alt, Special Issue, 8 pages.

De Barros MP, Lemos M, Maistro EL, Leite MF, Sousa JPB, Bastos JK, de Andrade SF. 2008. Evaluation of antiulcer activity of the main phenolic acids found in Brazilian Green Propolis. J Ethnopharmacol, 120(3): 372-377.

de Groot AC. 2013. Propolis: A Review of Properties, Applications, Chemical Composition, Contact Allergy, and Other Adverse Effects. Dermatitis, 24(6): 263-282.

Değirmencioğlu HT. 2018. Evaluation of Phenolic Profile, Botanical Origin, Antioxidant And Antimicrobial Activities of Turkish Propolis. (Master Thesis), Yeditepe University, İstanbul.

Duarte S, Koo H, Bowen WH, Hayacibara MF, Cury JA, Ikegaki M, Rosalen PL. 2003. Effect of a novel type of propolis and its chemical fractions on glucosyltransferases and on growth and adherence of mutans streptococci. Biol Pharm Bull, 26(4): 527-531.
Duman M, Ozpolat E. 2015. Effects of water extract of propolis on fresh shibuta (Barbus grypus) fillets during chilled storage. Food Chem, 189: 80-85.

EFSA. 2010. EFSA Panel on Dietetic Products, Nutrition Allergies: Scientific Opinion on the substantiation of health claims related to propolis (ID 1242, 1245, 1246, 1247, 1248, 3184 ) and flavonoids in propolis (ID 1244, 1644, 1645, 3526, $3527,3798,3799)$ pursuant to Article 13 (1) of Regulation (EC) No 1924/2006. EFSA journal, 8(10): 1810.

El-Bassiony T, Saad NM, El-Zamkan MA. 2012. Study on the antimicrobial activity of Ethanol Extract of Propolisagainst enterotoxigenic Methicillin-Resistant Staphylococcus aureus in lab prepared Ice-cream. Veterinary World, 5(3).

Falcao SI, Vilas-Boas M, Estevinho LM, Barros C, Domingues MRM, Cardoso SM. 2010. Phenolic characterization of Northeast Portuguese propolis: usual and unusual compounds. Anal Bioanal Chem, 396(2): 887-897.

Fan YP, Guo LW, Hou WF, Guo C, Zhang WM, Ma X, Ma L, Song XP. 2015. The Adjuvant Activity of Epimedium Polysaccharide-Propolis Flavone Liposome on Enhancing Immune Responses to Inactivated Porcine Circovirus Vaccine in Mice. Evid-Based Compl Alt.

Feas X, Pacheco L, Iglesias A, Estevinho LM. 2014. Use of Propolis in the Sanitization of Lettuce. Int J Mol Sci, 15(7): 12243-12257.

Funakoshi-Tago M, Okamoto K, Izumi R, Tago K, Yanagisawa K, Narukawa Y, Kiuchi F, Kasahara T, Tamura H. 2015. Antiinflammatory activity of flavonoids in Nepalese propolis is attributed to inhibition of the IL-33 signaling pathway. International immunopharmacology, 25(1): 189-198.

Gutiérrez-Cortés C, Suarez Mahecha H. 2014. Antimicrobial Activity Of Propolis And Its Effect On The Physicochemical And Sensoral Characteristics In Sausages. Vitae, 21(2): 90-96.

Han SK, Park HK. 2002. Accumulation of thiobarbituric acidreactive substances in cured pork sausages treated with propolis extracts. J Sci Food Agr, 82(13): 1487-1489.

Havsteen B. 1983. Flavonoids, a Class of Natural-Products of High Pharmacological Potency. Biochem Pharmacol, 32(7): 1141-1148.

Hosnuter M, Gurel A, Babuccu O, Armutcu F, Kargi E, Isikdemir A. 2004. The effect of CAPE on lipid peroxidation and nitric oxide levels in the plasma of rats following thermal injury. Burns, 30(2): 121-125.

Huang SA, Zhang CP, Wang K, Li GQ, Hu FL. 2014. Recent Advances in the Chemical Composition of Propolis. Molecules, 19(12): 19610-19632.

Ishida Y, Gao R, Shah N, Bhargava P, Furune T, Kaul SC, Terao K, Wadhwa R. 2018. Anticancer Activity in Honeybee Propolis: Functional Insights to the Role of Caffeic Acid Phenethyl Ester and Its Complex With -Cyclodextrin. Integr Cancer Ther, 17(3): 867-873.

Koc AN, Silici S, Mutlu-Sariguzel F, Sagdic O. 2007. Antifungal activity of propolis in four different fruit juices. Food Technol Biotech, 45(1): 57-61.

Kouidhi B, Zmantar T, Bakhrouf A. 2010. Anti-cariogenic and anti-biofilms activity of Tunisian propolis extract and its potential protective effect against cancer cells proliferation. Anaerobe, 16(6): 566-571.

Kumazawa S, Hamasaka T, Nakayama T. 2004. Antioxidant activity of propolis of various geographic origins. Food Chem, 84(3): 329-339.

Moreira L, Dias LG, Pereira JA, Estevinho L. 2008. Antioxidant properties, total phenols and pollen analysis of propolis samples from Portugal. Food and Chemical Toxicology, 46(11): 3482-3485.

Narbona E, García-García E, Vázquez-Araújo L, CarbonellBarrachina ÁA. 2010. Volatile composition of functional 'a la Piedra'turrón with propolis. International journal of food science \& technology, 45(3): 569-577. 
Noori A, Al-Ghamdi A, Ansari MJ, Al-Attal Y, Salom K. 2012. Synergistic effects of honey and propolis toward drug multiresistant Staphylococcus aureus, Escherichia coli and Candida albicans isolates in single and polymicrobial cultures. International journal of medical sciences, 9(9): 793.

Oliveira AP, Franca HS, Kuster RM, Teixeira LA, Rocha LM. 2010. Chemical composition and antibacterial activity of Brazilian propolis essential oil. J Venom Anim Toxins, 16(1): 121-130.

Osés SM, Melgosa L, Pascual-Maté A, Fernández-Muiño MA, Sancho MT. 2015. Design of a food product composed of honey and propolis. J Apicult Res, 54(5): 461-467.

Ozcan M. 2000. Use of propolis extract as a natural antioxidant for plant oils. Grasas Y Aceites, 51(4): 251-253.

Ozdemir AE, Candir EE, Kaplankiran M, Soylu EM, Sahinler N, Gul A. 2010. The effects of ethanol-dissolved propolis on the storage of grapefruit cv. Star Ruby. Turk J Agric For, 34(2): 155-162.

Ozturk I. 2015. Antifungal Activity of Propolis, Thyme Essential Oil and Hydrosol on Natural Mycobiota of Sucuk, a Turkish Fermented Sausage: Monitoring of Their Effects on Microbiological, Color and Aroma Properties. J Food Process Pres, 39(6): 1148-1158.

Passos FR, Mendes FQ, Cunha MCD, Pigozzi MT, Carvalho AMXD. 2016. Propolis Extract in Postharvest Conservation Banana'Prata'. Revista Brasileira de Fruticultura, 38(2).

Pastor C, Sanchez-Gonzalez L, Marcilla A, Chiralt A, Chafer M, Gonzalez-Martinez C. 2011. Quality and safety of table grapes coated with hydroxypropylmethylcellulose edible coatings containing propolis extract. Postharvest Biol Tec, 60(1): 64-70.

Pobiega K, Kraśniewska K, Gniewosz M. 2018. Application of propolis in antimicrobial and antioxidative protection of food quality-A review. Trends in Food Science \& Technology, 83: 53-62.

Quiroga EN, Sampietro DA, Soberon JR, Sgariglia MA, Vattuone MA. 2006. Propolis from the northwest of Argentina as a source of antifungal principles. J Appl Microbiol, 101(1): 103-110.

Russo A, Cardile V, Sanchez F, Troncoso N, Vanella A, Garbarino J. 2004. Chilean propolis: antioxidant activity and antiproliferative action in human tumor cell lines. Life sciences, 76(5): 545-558.

Russo A, Longo R, Vanella A. 2002. Antioxidant activity of propolis: role of caffeic acid phenethyl ester and galangin. Fitoterapia, 73: S21-S29.

Sawicka D, Car H, Borawska MH, Niklinski J. 2012. The anticancer activity of propolis. Folia Histochem Cyto, 50(1): 25-37.

Seidel V, Peyfoon E, Watson DG, Fearnley J. 2008. Comparative study of the antibacterial activity of propolis from different geographical and climatic zones. Phytother Res, 22(9): 12561263.

Sforcin JM. 2007. Propolis and the immune system: a review. J Ethnopharmacol, 113(1): 1-14.

Silva-Carvalho R, Baltazar F, Almeida-Aguiar C. 2015. Propolis: a complex natural product with a plethora of biological activities that can be explored for drug development. EvidBased Compl Alt, Special Issue, 2015:1-29.
Silva JC, Rodrigues S, Feas X, Estevinho LM. 2012. Antimicrobial activity, phenolic profile and role in the inflammation of propolis. Food and Chemical Toxicology, 50(5): 1790-1795.

Spinelli S, Conte A, Lecce L, Incoronato AL, Del Nobile MA. 2015. Microencapsulated Propolis to Enhance the Antioxidant Properties of Fresh Fish Burgers. J Food Process Eng, 38(6): 527-535.

Takaisikikuni NB, Schilcher H. 1994. Electron-Microscopic and Microcalorimetric Investigations of the Possible Mechanism of the Antibacterial Action of a Defined Propolis Provenance. Planta Med, 60(3): 222-227.

Thamnopoulos IAI, Michailidis GF, Fletouris DJ, Badeka A, Kontominas MG, Angelidis AS. 2018. Inhibitory activity of propolis against Listeria monocytogenes in milk stored under refrigeration. Food Microbiol, 73: 168-176.

Toreti VC, Sato HH, Pastore GM, Park YK. 2013. Recent progress of propolis for its biological and chemical compositions and its botanical origin. Evid-Based Compl Alt, 2013.

Turan I, Demir S, Misir S, Kilinc K, Mentese A, Aliyazicioglu Y, Deger O. 2015. Cytotoxic effect of Turkish propolis on liver, colon, breast, cervix and prostate cancer cell lines. Tropical Journal of Pharmaceutical Research, 14(5): 777-782.

Ugur A, Arslan T. 2004. An in vitro study on antimicrobial activity of propolis from Mugla province of Turkey. J Med Food, 7(1): 90-94.

Valente MJ, Baltazar AF, Henrique R, Estevinho L, Carvalho M. 2011. Biological activities of Portuguese propolis: Protection against free radical-induced erythrocyte damage and inhibition of human renal cancer cell growth in vitro. Food and Chemical Toxicology, 49(1): 86-92.

Vardar-Unlu G, Silici S, Unlu M. 2008. Composition and in vitro antimicrobial activity of Populus buds and poplar-type propolis. World J Microb Biot, 24(7): 1011-1017.

Vargas-Sanchez RD, Torrescano-Urrutia GR, Acedo-Felix E, Carvajal-Millan E, Gonzalez-Cordova AF, Vallejo-Galland B, Torres-Llanez MJ, Sanchez-Escalante A. 2014. Antioxidant and Antimicrobial Activity of Commercial Propolis Extract in Beef Patties. J Food Sci, 79(8): C1499C1504.

Watanabe MAE, Amarante MK, Conti BJ, Sforcin JM. 2011. Cytotoxic constituents of propolis inducing anticancer effects: a review. Journal of Pharmacy and Pharmacology, 63(11): 1378-1386.

Yang C, Luo LP, Zhang HJ, Yang X, Lv Y, Song HL. 2010. Common aroma-active components of propolis from 23 regions of China. J Sci Food Agr, 90(7): 1268-1282.

Yang WC, Wu ZH, Huang ZY, Miao XQ. 2017. Preservation of orange juice using propolis. J Food Sci Tech Mys, 54(11): 3375-3383.

Yildirim A, Duran GG, Duran N, Jenedi K, Bolgul BS, Miraloglu M, Muz M. 2016. Antiviral activity of hatay propolis against replication of herpes simplex virus type 1 and type 2 . Medical science monitor: international medical journal of experimental and clinical research, 22: 422.

Zam A, Othman M. 2018. Antioxidant Activity and other Physicochemical Characteristics of Different Propolis Extracts. Journal of Pharmacy and Nutrition Sciences, 8(2): 59-67. 